\title{
MIGRATION CONTROL À LA KHARTOUM: EU EXTERNAL ENGAGEMENT AND HUMAN RIGHTS PROTECTION IN THE HORN OF AFRICA
}

\author{
Lutz Oette, School of Law, SOAS University of London
}

\section{Mohamed Abdelsalam Babiker, Department of International and Comparative Law, University of Khartoum}

\begin{abstract}
This article examines the European Union - Horn of Africa Migration Route Initiative (the Khartoum Process), which is primarily aimed at combating human trafficking and smuggling in the region. It probes this partnership model in the field of external migration control from a human rights and refugee law perspective. Instead of being based on a human rights approach, the Khartoum Process has relied on a managerial, project-based approach to the complex realities of mixed migration in the Horn of Africa. The article uses Sudan as a case study, due to its critical role in the Khartoum Process. It identifies systemic weaknesses in Sudan's law and practice, which cast serious doubts on Sudan's ability to combat trafficking and smuggling in conformity with international standards, and its reliability as a partner in "migration management". It also shows how the Khartoum Process risks undermining the coherence of the European Union's external policy, particularly in respect of human rights protection in the region. These findings corroborate critiques of, and accentuate concerns about flawed partnership models and externalisation policies driven by imperatives of migration control. The article concludes by sketching out an alternative approach based on attention to context, process and respect for human rights.
\end{abstract}




\section{INTRODUCTION}

The European Union (EU), as part of its external relations, has responded to migration and refugee movements from its neighbouring continents by pursuing a number of bilateral (e.g. Libya, Turkey) and multilateral (e.g. the Rabat process on Western migration routes) initiatives designed to reduce the number of those reaching its borders. In November 2014, the EU-Horn of Africa (HoA) Migration Route Initiative, also referred to as the Khartoum Process, was added to the growing number of "migration management partnerships". It is a political process at ministerial level that brings together the EU, its member States, the African Union (AU) Commission and States from the region. ${ }^{1}$ The Khartoum Process is a response to the large number of migrants and refugees ${ }^{2}$ from the HoA. ${ }^{3}$ Persons seeking to leave their countries and the region increasingly have to rely on smuggling and many of them have been subjected to trafficking. ${ }^{4}$ These developments have resulted in estimated tens of thousands of trafficking victims since $2009,{ }^{5}$ most of whom are Eritreans. ${ }^{6}$ Sudan serves as "the centre for the transit of victims from the Horn to Europe through Libya or Egypt and the Mediterranean sea."7 This situation provides the context for the primary focus of the Khartoum Process, namely "to prevent

\footnotetext{
${ }^{1}$ Djibouti, Eritrea, Ethiopia, Kenya, Somalia, South Sudan, Sudan as countries from the HoA, and Egypt, Tunisia and Libya due to their role as transit countries.

${ }^{2}$ The article refers to refugees as those who qualify under art. 1 of the Convention Relating to the Status of Refugees, 1951, 189 UNTS 150, 28. Jul. 1951 (entry into force: 22 Apr. 1954), the Protocol relating to the Status of Refugees, 606 UNTS 267 (entry into force: 4 Oct 1967) and the 1969 Convention Governing the Specific Aspects of Refugee Problems in Africa, 1001 UNTS 45 (entry into force 20 Jun 1974).

${ }^{3}$ Somalia, Sudan, South Sudan and Eritrea are among the ten major source countries of refugees worldwide UNHCR, Global Trends 2015, 2016, 16. 89\% of Eritreans, 68\% of Somali and 47\% of Sudanese asylum-seekers were given status (refugee, subsidiary protection, humanitarian reasons) in EU member States. See A. Bitoulas, "Population and social conditions", Eurostat, Data in focus, 3/2015, 13.

${ }^{4}$ Sahan/Igad, Human Trafficking and Smuggling on the Horn of Africa-Central Mediterranean Route, Feb. 2016, 67, available at: www.eritreanrefugees.org/wp-content/uploads/2016/02/IGAD-Sahan-2015-Trafficking-Report.pdf (last visited 5 Oct. 2016); SIHA, Letters from Eritrea: Refugee women tell their story, Kampala, 2013.

${ }^{5}$ UNHCR, Smuggling and Trafficking from the East and Horn of Africa, Progress Report, 2015, 2.

${ }^{6}$ Ibid.

${ }^{7}$ Life \& Peace Institute, Human Trafficking and Smuggling in the Horn of Africa: Patterns, Dynamics, and Criminal Networks, Oct. 2015, 3, available at: http://ife-peace.org/wp-content/uploads/2015/10/Human-Trafficking-andSmuggling-in-the-Horn-of-Africa.pdf (last visited 5 Oct. 2016), 6; Sahan/Igad, Human Trafficking and Smuggling, $9,10$.
} 
and tackle the challenges of human trafficking and smuggling of migrants, ${ }^{\circ 8}$ which foregrounds the illegality of movement and adopts a criminal law approach with the goal of "better managing" migration.

The United Nations (UN) Secretary-General, in his report on large movements of refugees and migrants, referred to the Khartoum Process as one of the regional initiatives ${ }^{9}$ that "can underpin collective efforts to build mechanisms for improved future responses." $10 \mathrm{He}$ considered "creating a 'deal' in which responsibilities were shared among countries of origin, transit and destination and involved both humanitarian responses and development solutions" to be a key success factor. ${ }^{11}$ The subsequent UN General Assembly's New York Declaration for Refugee and Migrants "took note" of the Khartoum Process as a regional initiative. ${ }^{12}$ This positive vision of regional initiatives forms part of a broader development, in which regional partnerships have been identified as important components of international migration governance. ${ }^{13}$ The turn to regional initiatives as a policy instrument of migration control has attracted critical scrutiny. In the literature on migrant and security studies, regional initiatives have been viewed as a manifestation of the externalisation and outsourcing of migration control, in response to the failure of unilateral repressive measures. ${ }^{14}$ The "proliferation of informal, process-oriented, experimental forms of transgovernmental governance, promoted by countries of destination in their relations with countries of origin and transit" is not the purported panacea built on equal partnerships. ${ }^{15}$ Instead, it is marked by power asymmetry and conditionality, with the partnership discourse "reflect[ing] the continuing predominance of destination countries'

${ }^{8}$ Declaration of the Ministerial Conference of the Khartoum Process (EU-Horn of Africa Migration Route Initiative), Rome, 28 Nov. 2014, 4 (emphasis added). The terminology used does not acknowledge that many "migrants" from the region are known to be refugees.

${ }^{9}$ UN Secretary-General, In Safety and dignity: addressing large movements of refugees and migrants, UN Doc. A/70/59, 21 Apr. 2016, para. 44.

${ }^{10}$ Ibid., para. 41.

${ }^{11}$ Ibid., para. 42.

${ }_{12}^{12}$ New York Declaration for Refugees and Migrants, UN Doc. A/71/L.1, 13 September 2016, para. 19.

${ }^{13}$ See in particular the International Agenda for Migration Management (2004). See on global migration governance, Report of the Special Rapporteur on the human rights of migrants, UN Doc. A/68/283, 7 Aug. 2013, paras. 8-26.

${ }^{14}$ See S. Lavenex and R. Stucky, “'Partnering' for migration in EU external relations”, in R. Kunz, S. Lavenex and M. Panizzon (eds.), Multilayered Migration Governance: the promise of partnership, London, Routledge, 2011, 116-142; and, further, J. Huysmans and V. Squire, "Migration and Security", in M. D. Cavelty and T. Balzacq (eds.), Routledge Handbook of Security Studies, 2nd ed., London, Routledge, 2017, 161-171.

${ }^{15}$ R. Kunz and S. Lavenex, Partnerships in international migration governance: the missing link?, SNIS Working Paper, (undated), available at www.snis.ch/system/files/2008_-_ndeg250_-_migration_partnerships.pdf, (last visited 15 Jun. 2017), 1, 2-13. 
concerns with immigration control rather than mobility, rights or development." ${ }^{16}$ This critique is echoed in the legal literature, in which bilateral and regional partnerships have been identified as measures designed to achieve migration control objectives while escaping legal constraints that international law imposes on States once individuals, particularly refugees, reach their jurisdiction. ${ }^{17}$ External anti-trafficking measures form part of this development, whereby ostensible humanitarian imperatives mask migration control objectives. ${ }^{18}$ These concerns are reflected in the work of the Special Rapporteur on the human rights of migrants, who warned that regional consultative processes "can lead to a dilution of normative standards and a lack of accountability, monitoring and oversight, thus potentially negatively affecting the human rights of migrants. $" 19$

The Khartoum Process is the latest example of such regional initiatives. Its focus on the HoA has raised widespread concern over the appropriateness of using the partnership model in the context of one of the most volatile regions in the world, marred by repressive regimes, armed conflicts, transnational crime, dire socio-economic conditions and forced displacement. This article builds on the critical literature on externalisation of migration governance and policy analysis of regional initiatives. Its aim is to probe the Khartoum Process from a refugee rights and human rights perspective, with a view to evaluating whether it provides a suitable model for migration partnerships in the context of the HoA. It examines whether the claim that the "promotion and respect of human rights constitute a cross-cutting issue of our cooperation" ${ }^{20}$ is borne out in the conception and implementation of the Khartoum Process, focusing on the following core questions: Is the process of the Khartoum Process informed by a human rights framework? Are the partners in the HoA capable of implementing the envisaged projects in conformity with applicable human rights and refugee rights standards? Does this partnership model compromise the ability and willingness of the EU and its member States to pursue a robust policy vis-à-vis countries such as Sudan on the protection of human rights? Sudan is used as a primary case study in the HoA to consider the rights implications of the Khartoum Process.

\footnotetext{
${ }^{16}$ Ibid., 2.

${ }^{17}$ J. Hathaway and T. Gammeltoft-Hansen, "Non-Refoulement in a World of Cooperative Deterrence", Columbia Journal of Transnational Law, 53, 2015, 235-284.

${ }^{18}$ M. Lee, "Human Trafficking and Border Control in the Global South", in K. F. Aas and M. Bosworth (eds.), The Borders of Punishment, Oxford, Oxford University Press, 2013, 128-145.

${ }^{19}$ Report of the Special Rapporteur, Aug. 2013, para. 73.

20 "Rome Declaration", 3.
} 
The situation in, and the role of Sudan is critical as it is a country of origin, transit and destination of mixed migration movements. It is also a State whose conduct has been at the forefront of regional and international human rights and humanitarian concerns, including over the alleged commission of international crimes. Against this background, Sudan has most readily embraced the Khartoum Process as a means of garnering political and financial capital and of ending its international isolation.

Based on an assessment of the initial phase of the Khartoum Process, in terms of its rationale, policy process and substantive focus, we argue that it serves to corroborate criticism of externalisation and regional initiatives as a form of governance that adversely affect the human rights of migrants and refugee rights. Instead of paying heightened attention, called for by the particular geographic context, to ensuring respect for human rights in the design, process and implementation of the initiative, the Khartoum Process replicates problematic partnership models. As such, it fails to provide a suitable model to address the multiple challenges faced by people and States in the HoA, and for EU action on questions of migration in, and from the region. Uncritical references in UN documents to the initiative as an example of international cooperation are misplaced, and should not inform policy making in this area, as they fail to contribute to develop a rights-based approach to international migration governance. Considering the apparent shortcomings of the Khartoum Process, we sketch out the parameters of an alternative approach that anchors any initiatives aimed at tackling the interrelated challenges of human rights violations, armed conflict and forced migration in the region in a rights-based framework.

\section{THE KHARTOUM PROCESS AND THE EU'S AND AU'S POLICY INITIATIVES ON MIGRATION}

The Khartoum Process forms part of the EU's external action in Africa, in which security and control paradigms have come to dominate in the field of migration. ${ }^{21}$ It is situated at the interface of regional, primarily $\mathrm{AU}$ and $\mathrm{EU}$, initiatives on migration, which have gathered pace over the

\footnotetext{
${ }^{21}$ See further, Kunz and Lavenex, Partnerships in international migration governance.
} 
last decade, particularly since 2014. ${ }^{22}$ The Global Approach to Migration and Mobility (GAMM) is the "overarching framework of EU external migration policy". ${ }^{23}$ GAMM rests on four pillars, namely "legal migration and mobility, [preventing and reducing] irregular migration and trafficking in human beings, international protection and asylum policy, and maximising the development impact of migration and mobility. ${ }^{24}$ It is to be implemented through dialogues "both by regional processes and at bilateral/national level with key partner countries." ${ }^{25}$ These "[d]ialogues will build on regular political steering, through high-level and senior official meetings, action plans, cooperation instruments and monitoring mechanisms, where relevant., ${ }^{26}$ GAMM explicitly mentions the Rabat Process ${ }^{27}$ and refers to "a possible additional sub-regional framework in the Horn of Africa/East Africa (to be further explored). ${ }^{28}$

In April 2014, the EU and AU committed themselves "to further dialogue and deepening of our cooperation in the field of migration and mobility within the framework of the Joint AfricaEU Strategy." ${ }^{29}$ To this end, they agreed on an Action Plan for 2014-2017, which focuses, inter alia, on strengthening efforts to combat trafficking in human beings and the fight against irregular migration. ${ }^{30}$ When Italy assumed the Council of the EU Presidency in July 2014, it set out the "external dimension of migration" as one of its key priorities:

We need to combine the necessary prevention of illegal migration - including through more effective border control policies - and the fight against smuggling and human

\footnotetext{
${ }^{22}$ For AU initiatives, see The Migration Policy Framework for Africa (AU), EX.CL/276 (IX), Jun. 2006; African Common Position on Migration and Development, EX.CL/277 (IX), 2006; Ouagadougou Action Plan to Combat Trafficking in Human Beings, Especially Women and Children, 2006, AU document EX.CL/313 (X), Annex IV, 2007; Revised AU Plan of Action on Drug Control and Crime Prevention, (2007-2012) CMDCCP/EXP/3(III), 2007; AU.Commit Campaign: When the fight against trafficking becomes a priority for Africa, 2010, available at: www.africa-eu-partnership.org/en/newsroom/all-news/launch-aucommit-campaign-against-human-trafficking-hornand-east-africa (last visited 5 Oct. 2016). See also IGAD Regional Migration Policy Framework, 45th Ordinary Session of the IGAD Council of Ministers, 2012.

${ }^{23} \operatorname{COM}(2011) 743,18$ Nov. 2011, 4.

${ }^{24}$ Ibid., 6.

${ }^{25}$ Ibid., 4 (emphasis in original).

${ }^{26} \mathrm{Ibid}$. (emphasis in original).

${ }^{27}$ See for a brief overview, International Centre for Migration Policy Development, "Rabat Process", available at: www.icmpd.org/our-work/migration-dialogues/rabat-process/ (last visited 5 Oct. 2016) and for a brief comparison of the Khartoum Process and the Rabat Process, T. Reitano, The Khartoum Process: A sustainable response to human smuggling and trafficking? Institute for Security Studies, Policy Brief 93, Nov. 2016, 6-7.

${ }^{28} \operatorname{COM}(2011) 743,8$.

${ }^{29}$ EU-Africa Declaration on Migration and Mobility, Fourth EU-Africa Summit, 2-3 Apr. 2014, 2.

${ }^{30}$ Ibid., 2-3.
} 
trafficking with the promotion of well-managed legal migration and mobility and the implementation of the Common European Asylum System. ${ }^{31}$

It also expressed its intention to "promote the development of a migration dialogue with the Countries of East Africa."32

In October 2014, the AU, together with the Government of Sudan, UN High Commissioner for Refugees (UNHCR) and the International Organisation for Migration (IOM) held a regional conference in Khartoum. Its stated aim was "to explore cooperation among the member states in the region in addressing the challenges of human trafficking and smuggling of migrants within and from the Horn of Africa, and to come up with a common approach in addressing this issue. ${ }^{\prime 33}$ The conference provided a forum for States in the region, including, for the first time, Eritrea, to set out what steps they had taken in respect of human trafficking and smuggling, and for the AU to develop its policy and action plans in collaboration with key institutions working in the field of refugee protection and international migration. Several representatives of participating States resisted EU attempts to include a cross reference to the "EU Khartoum Process", which was seen as usurping the AU process, in the AU Declaration adopted at the conference. ${ }^{34}$

The EU-HoA Migration Route Initiative (the Khartoum Process) itself was launched in Rome on 28 November 2014. 37 States $^{35}$ and the EU and AU Commissioners in charge of migration and development, as well as the EU High Representative/Vice President of the European Commission adopted the Declaration of the Ministerial Conference of the Khartoum Process (Rome Declaration). They agreed "to undertake concrete actions to prevent and tackle the challenges of human trafficking and smuggling of migrants between the Horn of Africa and Europe," 36 including

\footnotetext{
31 Europe: a fresh start, Programme of the Italian Presidency of the Council of the European Union, 2014,12 (emphasis added).

32 Ibid.

33 AU, UNHCR, IOM, Government of Sudan, “AU Convene a Regional Conference to Address Human Trafficking and Smuggling in the Horn of Africa”, Joint Press Release, 13 Oct. 2014, 1.

${ }^{34}$ Information shared with authors. See also critical comments by Reitano, The Khartoum Process, 4.

${ }^{35}$ The 28 EU member States and Djibouti, Egypt, Eritrea, Ethiopia, Kenya, Somalia, South Sudan, Sudan, Tunisia.

36 "Rome Declaration", 3.
} 
[tackling] irregular migration and criminal networks ... improving national capacity building in the field of migration management ... stepping up prevention measures ... establishing national strategies to strengthen horizontal coordination among all services ... identification and prosecution of criminal networks by enhancing national law enforcement agencies, and the judicial system responses ... improving or, where appropriate, establishing criminal law frameworks ... promoting a victim-centred approach ... promoting sustainable development ... developing a regional framework for return, including voluntary, and reintegration ... [and] where appropriate, on a voluntary basis and upon individual request of a country in the region, assisting the participating countries in establishing and managing reception centres, providing access to asylum processes in line with international law, if needed, improving camp services and security, screening mixed migratory flows and counselling migrants. ${ }^{37}$

The Khartoum Process is situated in the EU-Africa Action Plan on Migration and Mobility 2014-2017, ${ }^{38}$ and forms part of the EU HoA Regional Plan 2015-2020. ${ }^{39}$ It "will be steered by a group of core EU and African countries ${ }^{40}$ as well as by the European Commission, the European External Action Service [EEAS], on the EU side, and the AU Commission."41 Norway and Switzerland have become members of the Khartoum Process and several institutions have observer status. ${ }^{42}$ In parallel, States, such as the United Kingdom (UK) ${ }^{43}$ have embarked on their own bilateral dialogues on migration, or, in the case of Italy, even signed problematic Memoranda of Understanding on migration with Sudan ${ }^{44}$ and other States, which form part of a broader EU policy on migration. ${ }^{45}$ A series of subsequent developments that intensified EU external engagement on migration in Africa have had a significant bearing on the Khartoum Process. In April 2015, the European Council expressed its commitment, as part of its objective

\footnotetext{
${ }^{37}$ Ibid., 3-4.

${ }^{38}$ Ibid., 1.

39 Council Conclusions on the EU Horn of Africa Regional Action Plan 2015-2020, COAFR310 ACP 153 CFSP/PESC 686 DEVGEN 205, 13363/15 (2015), 17, 26,

${ }^{40}$ Italy, France, Germany, UK, Malta and Egypt, Eritrea, Ethiopia, South Sudan, Sudan.

41 "Rome Declaration", 5.

${ }^{42}$ IOM, UNHCR, United Nations Office on Drugs and Crime (UNODC).

${ }^{43}$ Foreign and Commonwealth Office, "Completion of UK-Sudan strategic dialogue”, 20-21 March, 22 Mar. 2016.

44 "Sudan, Italy sign MoU to stem crime and irregular migration”, Sudan Tribune, 5 Aug. 2016

${ }^{45}$ European Council, European Council Meeting Conclusions (25 and 26 June 2015) Conclusions, EUCO 22/15, CO EUR8 CONCL3, 26 Jun. 2015.
} 
of "preventing illegal migration flows" to "reinforce our political cooperation with African partners at all levels in order to tackle the cause of illegal migration and combat the smuggling and trafficking of human beings." European Agenda on Migration". ${ }^{47}$ The levels of action include "reducing the incentives for irregular migration," in which "[p]artnership with countries of origin and transit is crucial," border management, a strong common asylum policy, and a new policy on legal migration. ${ }^{49}$ In November 2015, European and African Heads of State and Government adopted the EU Valletta Plan of Action at the Valletta summit. The Plan is

designed to (1) address the root causes of irregular migration and forced displacement; (2) enhance cooperation on legal migration and mobility; (3) reinforce the protection of migrants and asylum seekers; (4) prevent and fight irregular migration, migrant smuggling and trafficking in human beings; and (5) work more closely to improve cooperation on return, readmission and reintegration. ${ }^{50}$

According to the EU, "[t]he existing mechanisms of the Rabat Process, the Khartoum Process and the Joint EU-Africa strategy will be used to monitor the implementation of the action plan." ${ }^{, 51}$ The Valletta Summit also led to the establishment of the Emergency Trust Fund for Stability and Addressing Root Causes of Irregular Migration and Displaced Persons in Africa (EUTF). The Fund is a "multi-year facility designed to fund projects that promote resilience, stability and security in the Sahel, Horn and [North Africa] regions, in addition to other funds available. ${ }^{, 52} € 714$ million of a total of $€ 1.8$ billion EUTF funds have been set aside for the HoA, to address root causes, improve conditions for refugees, internally displaced persons (IDPs) and host communities, and to strengthen migration management. ${ }^{53}$

\footnotetext{
46 "Special meeting of the European Council, 23 Apr. 2015 - statement" (emphasis added).

${ }^{47} \operatorname{COM}(2015) 240$ final.

${ }^{48}$ Ibid., 7-8.

${ }^{49}$ Ibid., 10-18. Subsequently, the Commission elaborated on "establishing a new partnership framework with third countries under the European Agenda on Migration", which referred to "country packages for 16 priority countries", including Ethiopia, Eritrea, Somalia and Sudan. COM(2016) 385 final, 7 Jun. 2016, 8.

${ }^{50}$ See "2015 Valletta Summit on Migration Action Plan", 11-12 Nov. 2015, 1.

51 See European Commission, "The EU Emergency Trust Fund Africa", available at: https://ec.europa.eu/europeaid/regions/africa/eu-emergency-trust-fund-africa_en (last visited 5 Oct. 2016).

${ }_{52}$ Ibid.

${ }^{53}$ Ibid.
} 
The Action Plan: Better Migration Management in Support of the Khartoum Process (BMM) is the first major initiative. In December 2015, €40 million were drawn for the BMM, which falls under EUTF's third objective, "namely improved migration management in countries of origin and transit." ${ }^{, 5}$ The BMM is to be implemented from April 2016 to March 2019 by several European and international organisations, including IOM and the UN Office on Drugs and Crime (UNODC), and is coordinated by the German Agency for International Cooperation (GIZ). ${ }^{55}$ The BMM embodies the twin focus on migration control and protection measures. It is expected to result in the development of national legislation in accordance with international standards, enhanced capacity "to manage migration effectively," "improved access to justice and to protection facilities" for migrants and victims of trafficking, and "greater awareness of risk associated with irregular migration." participants at the Khartoum Process first Steering Committee meeting." ${ }^{, 57}$ Effectively, therefore, priorities are set through the Khartoum Process and the Trust Fund finances (substantial parts of) projects such as the BMM planned as part of the process.

\section{THE KHARTOUM PROCESS AND A HUMAN RIGHTS-BASED FRAMEWORK}

Article 21(1) of the Treaty on European Union (TEU) provides that the EU's "action on the international scene shall be guided" by a set of principles, including the rule of law and human rights. ${ }^{58}$ This implies that the EU takes a human rights based approach when engaging in external action and partnerships, both substantively and in terms of a process guided by consultation, participation, transparency and accountability. ${ }^{59}$

\footnotetext{
${ }^{54}$ EUTF, Action Fiche for the implementation of the Horn of Africa Window, T05-EUTF-HoA-REG-09: Better Migration Management (Khartoum Process) (undated).

${ }^{55}$ The total amount for the BMM is $€ 46$ million, as Germany has provided a $€ 6$ million co-funding contribution. See $\operatorname{COM(2016)385~final.,~and,~for~the~project~website,~www.giz.de/en/worldwide/40602.html~(last~visited~} 4$ Jul. 2017).

${ }^{56}$ EUTF, Better Migration Management, 7-9.

${ }^{57}$ Ibid., 2.

${ }^{58}$ See Consolidated version of the Treaty on European Union and the Treaty on the Functioning of the European Union (2016/C 202/01), C 202/28.

${ }^{59}$ See on a human rights-based framework, Report of the Special Rapporteur on the human rights of migrants, UN Doc. A/71/285, 4 August 2016, para. 51.
} 
The Rome Declaration "recall[s] that promotion and respect of human rights constitute a cross-cutting issue of our cooperation," and includes references to rights and protection. It does not, however, specify how human rights are to be respected in the Khartoum Process. The latter has not been based on empirical research, and evaluation specific to the planned actions and the region to inform both policy making and the nature of measures taken. ${ }^{60}$ This concerns in particular the nature of migration, relevant human rights concerns in this regard, and practices relating to refugee protection, including an assessment of potentially adverse impacts of the planned actions.

The Khartoum Process has been largely developed at the inter-State and inter-regional institutions level. There has been some, albeit limited, involvement of relevant international organisations but virtually no consultation or meaningful participation of concerned communities in the region, that is the right-holders and intended beneficiaries, and civil society representatives. In essence, it is a top-down process whose approach reflects the interests of European and HoA States, though not necessarily in equal measure, ${ }^{61}$ with limited evidence that its partners have taken "into account the consequences of their decisions on the lives and rights of migrants." 62 The combination of a high-level policy dialogue at ministerial and Commission level on the one hand and technical project implementation on the other has also resulted in a lack of representative political participation, and democratic scrutiny, in the development of the policy. This has been compounded by the limited transparency of the process, which has been part of a strategy to give the process as little publicity as possible so as to minimise the risk of adverse political consequences. ${ }^{63}$ Debates in the European Parliament ${ }^{64}$ and parliamentary

\footnotetext{
${ }^{60}$ See further, also on the lack of participation and transparency more broadly, M. Stern, The Khartoum Process: Critical Assessment and Policy Recommendations, Istituto Affari Internazionali, IAI Working Papers 15/49, Dec. 2015, 12-13.

${ }^{61}$ The process has not been without tensions with respect to divergent policy priorities (an EU focus on irregular migration in contrast to an AU focus on responsibility sharing and channels of legal migration), a lack of ownership (such as in respect of needs assessment and implementation of projects) and a failure to deliver pledged funding. See on "power asymmetries" of regional consultative processes, Report of the Special Rapporteur, Aug. 2013, para. 75.

${ }^{62}$ Report of the Special Rapporteur, 2016, para. 51.

${ }^{63}$ Stern, Khartoum Process, 11-12. An official website was launched in November 2016 more than two years after the Rome Declaration, see www.khartoumprocess.net (last visited 4 Jul. 2017).

${ }^{64}$ See European Parliament, "Khartoum Process and the forthcoming 'EU-Horn of Africa Migration Route Initiative' (debate)", 17 Dec. 2014; European Parliament resolution of 6 Oct. 2016 on Sudan (2016/2911 (RSP)), paras. 16, 17.
} 
questions in countries such as Germany, Ireland, and the United Kingdom ${ }^{65}$ highlight the demand for greater involvement of political representatives, transparency, and monitoring. They articulate the unease that the nature of the Khartoum Process has generated, particularly in respect of its adverse impact on the rights of migrants and refugee rights given the record of human rights violations of partner States. Statements by civil society organisations and individual commentators reflect similar concerns. ${ }^{66}$ The brief analysis of the process to date demonstrates that it has largely ignored even basic components of a human rights-based approach. There is no clear indication of how human rights have informed the process as "a cross-cutting issue" as stipulated in the Rome Declaration. This finding reinforces criticism of externalisation and informal governance partnerships as mechanisms that prioritise migration control over rights protection, rather than marrying pragmatism with principle.

\section{SUBSTANTIVE FOCUS OF THE KHARTOUM PROCESS}

\subsection{The nexus between human trafficking/smuggling and irregular migration}

The Khartoum Process, though forming part of broader EU-AU policies on migration, focuses, at least in its initial phase, firmly on trafficking and smuggling of vulnerable persons. The problem of, and extreme suffering caused by trafficking, and certain forms of smuggling in the region has been well documented. ${ }^{67}$ As rightly highlighted in the Rome Declaration, human trafficking is a

\footnotetext{
${ }^{65}$ See Antwort der Bundesregierung auf die Kleine Anfrage der Abgeordneten Niema Movassat, Annette Groth, Heike Hänsel, weiterer Abgeordneter und der Fraktion DIE LINKE, Drucksache 18/8220: Migrationskontrolle am Horn von Afrika, 10 May 2016; Antwort der Bundesregierung auf die Kleine Anfrage der Abgeordneten Uwe Kekeritz, Claudia Roth (Augsburg), Luise Amtsberg, weiterer Abgeordneter und der Fraktion BÜNDNIS 90/DIE GRÜNEN, Drucksache 18/8682: EU-Migrations- und Grenzmanagement in Afrika, 23 Jun. 2016; in the UK, Parliamentary Questions for the 2015-16 session (dates for question and answer) by Lord Hylton, HL1149 (12/26 Jul. 2016); Lord Chidgey, HL1047, 1048 and 1050 (6/14 Jul. 2016) and HL17 (18 May 2016/7 Jun. 2016); Lord Sheikh, HL1252 (14 Jul. 2016/2 Aug. 2016); Ireland, Written answer of the Department of Foreign Affairs and Trade, Question by Seán Crown [46715/15] 13 Jan. 2016.

${ }^{66}$ Civil Society Statement on Push Factors in Sudan and the Khartoum Process, 2016, available at: http://sudanconsortium.org/darfur_consortium_actions/pressreleases/2016/Civil\%20Society\%20Statement $\% 20$ on $\% 2$ 0Push\%20Factors\%20in\%20Sudan\%20and\%20the\%20Khartoum\%20Process\%20final\%20(1).pdf (last visited 5 Oct. 2016); R. Marsden, "The migration crisis and the Horn of Africa: the Khartoum Process", Confrontations Europe, 11 Oct. 2015; Human Rights Watch, "EU/AU: Put Rights at Heart of Migration Efforts", New York, 9 Nov. 2015; A. Adam and A. Robinson, "EU sidesteps human rights standards", Sudan Tribune, 26 Jul. 2016, available at: www.sudantribune.com/spip.php?article59733 (last visited 5 Oct.2016).

${ }^{67}$ Y. B. Malk, "Human Trafficking and Human Smuggling to and from Eastern Sudan: Intended and Unintended Consequences of States", Policies, Academic Journal of Interdisciplinary Studies, 5(1), Mar. 2016, 215-225; Human Rights Watch, I Want to Lie Down and Die, Trafficking and Torture of Eritreans in Sudan and Egypt, New York,
} 
serious crime and human rights violation. ${ }^{68}$ Traffickers often threaten the well-being if not lives of refugees and migrants; while smugglers may equally do so, they also provide an essential, albeit illegal, service to those seeking to flee their countries. ${ }^{69}$ The framing of the Khartoum Process, particularly in terms of the nexus between irregular migration and smuggling/trafficking is problematic. Several authors have highlighted how the supposedly humanitarian concern to combat human trafficking and smuggling has been used to conceal the underlying purpose of (external) migration control, ${ }^{70}$ and how migration control as an overall EU migration policy fuels the very practices that are then subject to cooperative initiatives to combat the same. ${ }^{71}$ The UN Special Rapporteur on the Human Rights of Migrants, in his analysis of GAMM,

... regret[ted] the linking of irregular migration with human trafficking, which may falsely give the impression that irregular migration is a criminal offence, in line with trafficking. While the smuggling of migrants may constitute a criminal offence, irregular migration does not, and should thus not be linked to security issues and crime. ${ }^{72}$

The Rome Declaration expresses its deep concerns about "lives endangered by hazardous journeys across desert and sea." undertaking action to try to avoid such tragedies in full observance of human rights and human dignity." ${ }^{, 74}$ However, there is no mention or acknowledgement that restrictive migration control and the limited scope of legal migration channels to the EU are critical factors contributing to this situation, and thereby call current EU policies into question. Instead, the thrust of the problems identified, and the areas of cooperation are all in the HoA region. Mixed migration,

2014; M. van Reisen et al., The Human Trafficking Cycle: Sinai and beyond, Oisterwijk, Wolf Legal Publishers, 2014; L. Lijnders and S. Robinson, "From the Horn of Africa to the Middle East: Human trafficking of Eritrean asylum seekers across borders", Anti-Trafficking Review, 2, 2013, 137-154.

68 "Rome Declaration", 2.

${ }^{69}$ See further P. Tinti and T. Reitano, Migrant, Refugee, Smuggler, Saviour, London, Hurst \& Company, 2016.

${ }^{70}$ See on the role of humanitarian language in migration policy particularly B. S. Chimni, "Birth of a Discipline: From Refugee to Forced Migration Studies", Journal of Refugee Studies, 22, 2009, 11-29.

${ }^{71}$ Lee, "Human Trafficking"; F. Crépeau, "Rejecting Criminalisation and Externalisation: Moving from Enforced Closure to Regulated Mobility", Georgetown Law Journal, 104, 2015, 115-123, 120: "Irregular migration is the direct result of policies prohibiting immigration."

${ }^{72}$ Report of the Special Rapporteur on the human rights of migrants, François Crépeau, Regional study: management of the external borders of the European Union and its impact on the human rights of migrants, UN Doc. A/HRC/23/46, 24 Apr. 2013, para. 32.

73 "Rome Declaration", 2.

${ }^{74}$ Ibid. 
and trafficking and smuggling of vulnerable persons, are portrayed as regional, African issues, rather than a joint, international problem. The key areas of cooperation identified in its text suggest that the main addressees are States in the region rather than the EU and its member States. ${ }^{75}$ Notwithstanding the commitment to better organised legal migration and managed human mobility between regions, ${ }^{76}$ the Declaration focuses on how initiatives within African member States can meet the joint commitments made therein. This includes ensuring "effective protection to refugees, asylum seekers, as well as to internally displaced persons, and to provide for due access to asylum processes in line with international law."77 These features replicate a broader pattern of EU external action in which the newly created partners are made responsible for migration control measures. ${ }^{78}$

The authors of the Rome Declaration "express our firm political commitment to expand the Khartoum Process into a sustainable regional dialogue on migration and mobility which will address the root causes of irregular migration and mixed migration flows in a comprehensive and balanced way," which includes efforts to foster development and to provide channels for legal migration. ${ }^{79}$ This de facto relegation of key concerns for the HoA region to an unknown future date has made the Khartoum Process appear distinctively lopsided, a fact that has already met with criticism from African States. ${ }^{80}$

\subsection{Better Migration Management and its compatibility with rights protection}

An analysis of the main activities envisaged under the BMM as the first major project under the Khartoum Process demonstrates the challenges that its implementation poses to rights protection.

The first activity concerns "capacity building support to relevant Khartoum Process countries, in particular Eritrea, Somalia, South Sudan and Sudan, in drafting national legislation and policies on migration and border management [particularly human trafficking]." ${ }^{\text {81 }}$ This is an

\footnotetext{
${ }^{75}$ Ibid., 3-4.

${ }^{76}$ Ibid., 5.

${ }^{77}$ Ibid., 2.

${ }^{78}$ Kunz and Lavenex, Partnerships in international migration governance, 24.

79"Rome Declaration", 4-5. See proposals for measures to be taken in this regard, UNHCR Observations regarding the Rome Conference of the EU Horn of Africa Migration Route Initiative, 28 Nov. 2014 (undated), available at: www.unhcr.org/cgi-bin/texis/vtx/home/opendocPDFViewer.html?docid+54bd0a409 (last visited 5 Oct. 2016).

${ }^{80}$ See section 3.

81 EUTF, Better Migration Management, 7. See further GIZ, Description of the Action: Better Migration Management, Annex I to the Delegation Agreement CRIS No. [EUTF05-HoA-REG-20], 2016,, available at: www.giz.de/en/downloads/giz2016-en-bmm-description-of-action.pdf (last visited 4 Jul. 2017), 10: "To strengthen
} 
important activity as most States in the region do not have adequate legal frameworks in place. Sudan responded to the lack of adequate legislation by adopting several laws in 2014 and 2015. The new Asylum Regulation Act of 2014 remedies some shortcomings of the 1974 Asylum Regulation Act but restricts freedom of movement and does not provide for adequate judicial guarantees to challenge deportation orders and revocation of refugee status. ${ }^{82}$ The 2014 Combating of Human Trafficking Act (CHT Act) ${ }^{83}$ (there is no law on smuggling) ${ }^{84}$ has a broad definition of trafficking which is, however, not fully in line with the Palermo Protocol. ${ }^{85}$ It provides that the death penalty may be imposed for nine different aggravated acts of trafficking. ${ }^{86}$ Several of these acts do not meet the criteria of a "serious crime", which is one of the prerequisites for the imposition of the death penalty in accordance with international law where still recognised as an exception to the right to life. ${ }^{87}$ Its Article 25 provides for the protection of victims and witnesses. However, the CHT Act is silent on the right of a foreign victim to remain in the country, at least temporarily, or a duty of the State to consider granting a temporary or permanent stay in its territory. ${ }^{88}$ It also does not provide for an unequivocal prohibition of refoulement. $^{89}$ The United States Department of State, in its Trafficking in

national governments in pursuing a whole of government approach to migration and border governance with the aim to effectively address trafficking in persons and smuggling of migrants, thus allowing for regional policy harmonization and cooperation in accordance with the relevant international conventions and standards as well as regional policy frameworks."

${ }^{82}$ See art. 14(2)(a) (place of residence), as well as arts 11 (Revocation of refugee status) and 12 (Establishment of Council of Appeal and Procedures) of the Asylum Regulation Act, 2014.

83 The Act came into force on 3 Mar. 2014. A translated version of the Act is available at: www.ilo.org/dyn/natlex/docs/MONOGRAPH/99189/118286/F148132047/SDN99189\%20Eng.pdf (last visited 5 Oct. 2016).

${ }^{84}$ A Kassala State Act of 2010 regulates smuggling in Eastern Sudan but not human trafficking.

${ }^{85}$ The Act does not explicitly prohibit child trafficking in the absence of coercion and its definition of exploitation in art. 7 is not aligned with the Palermo Protocol (Protocol to Prevent, Suppress and Punish Trafficking in Persons, Especially Women and Children, supplementing the United Nations Convention against Transnational Organized Crime, 2237 UNTS 319).

${ }^{86}$ Art. 9(2) of the CHT Act.

${ }^{87}$ See art. 6(2) of the ICCPR and African Commission on Human and Peoples' Rights (ACHPR), General Comment No.3 on the African Charter on Human and Peoples' Rights: The Right to Life (Article 4), (Nov. 2015), para. 24.

${ }^{88}$ Art. 7 of the Palermo Protocol: “... each State Party shall consider adopting legislative or other appropriate measures that permit victims of trafficking in persons to remain in its territory, temporarily or permanently, in appropriate cases". See further A. T. Gallagher, The International Law of Human Trafficking, Cambridge, Cambridge University Press, 2010, 320-323.

${ }^{89}$ The prohibition of refoulement in line with art. 33 of the 1951 Refugee Convention is recognised in art. 28(2) of the Asylum Regulation Act 2014 but Sudanese law does not provide for it outside of the asylum law context. This applies to expulsions that place returned individuals at the risk of serious violations such as torture, which may include human trafficking. 
Persons Report $2017,,^{90}$ found a number of deficiencies in respect of prevention, prosecution, in particular impunity of officials, and protection, ${ }^{91}$ which reflects the findings of other observers on the measures taken by Sudan in respect of human trafficking. ${ }^{92}$ Under the BMM, Sudan has requested "[a]ssistance to develop or implement comprehensive migration policy, including human trafficking regulations, ${ }^{, 93}$ which should, based on the foregoing analysis, also include reviewing any shortcomings of the CHT Act itself.

The second BMM activity concerns "capacity-building support" in the form of "training, technical assistance and provision of relevant equipment, for judiciary and border management authorities to better address migration and border management." ${ }^{94}$ This is arguably the most problematic project component. The building of capacity of law enforcement agencies, border forces and the judiciary presupposes the existence of a criminal justice system that is at least capable of functioning in accordance with the rule of law. This is an essential criterion as the Khartoum Process, and EU policy more broadly, stress the need for the protection of refugee rights and the human rights of migrants. ${ }^{95}$ Sudan has centralised law enforcement capacity but its criminal justice system is grossly deficient from a refugee rights and human rights perspective. Investigators in criminal cases, particularly those with a political dimension, have repeatedly resorted to arbitrary arrest and detention, torture and other ill-treatment ${ }^{96}$ and members of law enforcement agencies enjoy immunity for their conduct. ${ }^{97}$ Lack of access to justice, especially in the form of effective remedies in cases of human rights violations, is systemic, as recognised by the African Commission on Human and Peoples' Rights (ACHPR) and other human rights treaty bodies. ${ }^{98}$ A number of crimes are subject to disproportionate punishments, including the death

\footnotetext{
90 The Trafficking in Persons report is considered reliable. However, it has been criticized as a "recipe for hegemonic governance through surveillance, aimed at disciplining the globe", C. Dauvergne. Making People Illegal, What Globalization Means for Migration and Law, Cambridge, Cambridge University Press, 2008, 76. See on concerns over interference in respect of "strategically important countries", J. Szep and M. Spetalnick, "Special Report: State Department watered down human trafficking report”, Reuters, 3 Aug. 2015.

${ }^{91}$ US Department of State, Trafficking in Persons Report, Jun. 2017, 371-373.

${ }^{92}$ See Malk, "Human trafficking", 220-222, for a brief assessment.

${ }^{93}$ EUTF, Better Migration Management, 13.

${ }^{94}$ Ibid., 7. GIZ, Description of the Action, 13: "To strengthen the capacity of all institutions and agencies responsible for migration and border managements."

95 "Rome Declaration", 2, 3.

${ }^{96}$ Human Rights Committee (HRCtee), Concluding observations on the fourth periodic report of the Sudan, UN Doc. CCPR/S/SDN/CO/4, 19 Aug. 2014, paras. 15, 18.

${ }^{97}$ Arts. 42(2) of the 2007 Armed Forces Act, 45(1) of the 2008 Police Act and 52 of the 2010 National Security Act.

${ }^{98}$ See e.g. Monim Elgak, Osman Hummeida and Amir Suliman (represented by FIDH and OMCT) v. Sudan, Communication 379/09 (2014), para. 69.
} 
penalty, which has been imposed and executed in violation of fair trial standards. ${ }^{99}$ Human trafficking is classified as a transnational crime (as in the case of terrorism offences) and tried by special courts under special rules and procedures which lack basic fair trial guarantees. ${ }^{100}$ Conversely, there is no effective system of victim and witness protection or referral system. ${ }^{101} \mathrm{~A}$ member of the National Committee for Combating Human Trafficking acknowledged that the Committee does not have direct contact with victims of human trafficking, and that there are no safe houses for victims, ostensibly due to lack of international funding. ${ }^{102}$

Sudan has repeatedly taken measures that are prima facie incompatible with its obligations under the Refugee Convention and other treaties. On several occasions, including after $2014,{ }^{103}$ persons coming from neighbouring countries, particularly Eritrea, have been charged with unlawfully entering the country under the 1994 Passports and Immigration Act and, as from 2015, under the new Passports and Immigration Act, which provides for wide powers of deportation for illegal entry, without judicial review. ${ }^{104}$ This practice can also be attributed to confusion amongst law enforcement agencies as a result of multiple legal reforms, which are partly, as in the Passports and Immigration Act, in response to the Khartoum Process. The 2014 CHT Act is not complemented by adequate anti-smuggling and migration laws, and refugees are often dealt with under the new Passports and Immigration Act, rather than the new Asylum

\footnotetext{
${ }^{99}$ HRCtee, Concluding observations: Sudan, para. 14.

100 To date, outcomes of prosecutions for human trafficking have been characterised by insufficient, rather than excessive, punishments. US, Trafficking in Persons Report, 372. See for relevant statistics, Report on Human Trafficking, addressed to the General Prosecutor, Ministry of Justice, Legal Department, Gadaref state, 24 Nov. 2015, No WH/NH/41/A/1 (Arabic), 2: Year 2014; 38 filed cases; three under investigation; 35 prosecuted resulting either in a fine or 2-3 month imprisonment where fine not paid. Year 2015: 31 filed cases, five under investigation, 26 prosecuted resulting in either fine or short-term imprisonment, and Report of the Prosecution of the Kasslaa state, Legal Department, Ministry of Justice, 30 May 2016, No WH/AN/WK (Arabic), 2 (cases still pending). See, however, reports that, "in October 2016, a court in Kassala State in East Sudan sentenced eight people convicted of human trafficking to death" (with the final execution pending Presidential assent in July 2017), Amnesty International, Human rights impacts and risks associated with the Khartoum Process, Submission to the UK AllParty Parliamentary Group for Sudan and South Sudan, London, October 2016, Index: AFR 54/5337/2016, 3.

${ }^{101}$ See Report on Human Trafficking, 2015, ibid.

${ }^{102}$ Salih Amaar, 'Interview with Mr. Is'mail Omar Tairab', (Arabic) Eltaghyeer Newspaper, 28 Dec. 2016, available at www.altaghyeer.info/2016/12/28/\% \%AD (last visited 30 Dec. 2016). Note that art. 25 CHT Act stipulates that the State should provide adequate funding for victims and witness protection.

${ }^{103}$ See HRCtee, Concluding observations: Sudan, para. 23 and UNHCR, "UNHCR concerned over forced returns of refugee and asylum-seekers from Sudan", 4 Jul. 2014.

${ }^{104}$ Under art. 31(1) of the 1951 Refugee Convention, refugees should not be penalised for unlawful entry subject to certain conditions. See further on the 1994 Passports and Immigration Act, M. A. Babiker, Irregular Migration in Sudan: A Legal Perspective, Carim Analytic and Synthetic Notes-Circular Migration Series, Socio-political Module, CARIM-AS 2011/64, Robert Schuman Centre for Advanced Studies, San Domenico de Fiesole (FI), European University Institute, 2011.
} 
Regulation Act of 2014. In May 2016, for example, Sudanese authorities reportedly arrested and deported several hundred persons to Eritrea without giving them access to asylum status determination procedures. ${ }^{105}$ These measures risk constituting, or constitute a breach of Sudan's obligations not to refoule individuals at risk of persecution under the 1951 Refugee Convention and the African Protocol of 1969 on Aspects of Refugee Problems in Africa, and/or serious human rights violations, and therefore the principles agreed upon in the Khartoum Process. ${ }^{106}$

The envisaged provision of training and equipment to Sudanese law enforcement and security agencies is highly problematic. ${ }^{107}$ The BMM Action Fiche acknowledges the risk that: "Provision of equipment and trainings to sensitive national authorities (such as security services or border management) diverted for repressive aims." 108 This is a genuine risk in respect of agencies that have, and a regime which has, according to a number of well documented factfinding missions, cases and other sources, been responsible for serious human rights violations. ${ }^{109}$ A number of accounts of trafficked persons, particularly Eritreans, describe how Sudanese border guards have colluded with traffickers. ${ }^{110}$ These forms of complicity in criminal activities are part of a broader practice of corrupt and illicit conduct in which members of the National Intelligence and Security Services (NISS) and others are alleged to be involved. ${ }^{111}$ The known risk of abuse that the provision of training and equipment carries may, were it to materialise, expose the EU and its member states to allegations of complicity, and possibly litigation. ${ }^{112}$ The mitigating measures considered in the BMM, such as "senior level buy-in" and

${ }^{105}$ K. Siegrief, "Sudan and Eritrea crackdown on migrants amid reports of EU incentives", IRIN, 25 May 2016, available at: www.irinnews.org/news/2016/05/25/sudan-and-eritrea-crackdown-migrants-amid-reports-eu-incentives (last visited 5 Oct 2016).

${ }^{106}$ See further on non-refoulement in Sub-Saharan Africa, C. d'Orsi, Asylum-Seeker and Refugee Protection in SubSaharan Afria: The Peregrination of a Persecuted Human Being in Search of a Safe Haven, London, Routledge, 2016, 33-60.

${ }^{107}$ The Sudanese Ministry of Interior proposed, as an action under the BMM, training for immigration and other border management officials, and funding of equipment and personnel for a regional training centre. Improved border infrastructure at 17 crossing points (computers, cameras, scanners, servers, cars, aircraft) was in principle accepted by EUTF “but aircraft unlikely”. EUTF, Better Migration Management, 13.

${ }^{108}$ Ibid., 9.

${ }^{109}$ See e.g. Report of the International Commission of Inquiry on Darfur to the United Nations Secretary-General (25 Jan. 2005) and Compilation prepared by the Office of the United Nations High Commissioner for Human Rights in accordance with paragraph 15 (b) of the annex to Human Rights Council resolution 5/1 and paragraph 5 of the annex to Council resolution 16/21: Sudan, UN Doc. A/HRC/WG.6/25/SDN/2, 7 Mar. 2016.

${ }^{110}$ See e.g. HRW, I want to lie down, 28-30.

${ }^{111}$ Amnesty International, Sudan: Agents of Fear: The National Security Service in Sudan, London, 19 Jul. 2010, Index number: AFR 54/010/2010; S. Baldo, Khartoum's Economic Achilles' Heel: The intersection of war, profit, and greed, Washington, Enough Project, 2016.

${ }^{112}$ See Hathaway and Gammeltoft-Hansen, "Non-refoulement", 276-282. 
"reliance on well-experienced implementing partner with good political relations with the target countries" evince a political and instrumentalist mindset. ${ }^{113}$ This technical approach does not specify how it can ensure, or even minimise the risk that equipment and training is not used for repressive aims, particularly in a situation where a convergence of objectives (EU migration control measures and Sudanese access to valuable equipment) may result in a mutual interest to ignore any misuse. It also shows a lack of historical awareness of the multiple failures by countries such as Sudan to honour their international commitments. ${ }^{114}$

The other risks identified in EUTF's assessment suffer from similar shortcomings. They primarily focus on operational challenges in terms of project management (lack of follow up and political will, lack of incentives to renounce and fight corruption, inadequate resources) ${ }^{115}$ and ignore the fundamental challenge that cooperation with a repressive regime in the highly sensitive area of migration control and criminal justice may facilitate abuses, instead of preventing them. Indeed, the project may even incentivise a partner State to violate the rights of refugees and migrants in order to demonstrate its capacity to control migration. The proposed strengthening of the border in Sudan, while in principle a legitimate aim, is against this background risking greater exposure of smuggled or trafficked persons to Sudanese border guards who may abuse their powers (collusion in trafficking, extortion) or violate refugees' rights (refoulement at the border, or, following entry, arbitrary arrest and detention and eventual deportation without due process of law). The paramilitary Rapid Support Forces (RSF) ${ }^{116}$ have reportedly already been deployed to combat human trafficking and arrested several hundred "illegal immigrants" close to Sudan's northern borders (Libya, Egypt) and Sudanese

${ }^{113}$ EUTF, Better Migration Management, 10.

${ }^{114}$ See e.g. A. Alier, Southern Sudan: Too Many Agreements Dishonored, $2^{\text {nd }}$ edn., Exeter, Ithaca Press, 1999 , and A. Verjee, "Too Many Agreements Dishonoured", Revisited, Sudan Tribune, 6 Apr. 2011, available at: www.sudantribune.com/Too-Many-Agreements-Dishonoured,38503 (last visited 5 Oct. 2016).

${ }^{115}$ EUTF, Better Migration Management, 9.

${ }^{116}$ See on the RSF's role S. Baldo, Border Control from Hell: How the EU's migration partnership legitimizes Sudan's “militia state”, Enough Project, Washington, Apr. 2017; A. Kumar and O. Ismail, Janjaweed Reincarnate: Sudan's New Army of War Criminals, Washington, Enough Project and Satellite Sentinel Project, Jun. 2014; Twenty-third Report of the Prosecutor of the International Criminal Court to the UN Security Council pursuant to the UNSC 1593 (2005), 9 Jun. 2016, para. 15.

117 Terminology used by Commander Hametti, “Libya: Sudanese Force Arrests '300 Illegal Immigrants' Near Libya", Radio Dabanga, 5 Jul. 2016, available at: www.dabangasudan.org/en/all-news/article/sudanese-forcearrests-300-illegal-immigrants-near-libya (last visited 5 Oct. 2016). See also "Sudan's RSF militia arrests 600 illegal migrants near Libyan and Egyptian border", Sudan Tribune, 31 Jul. 2016, available at: www.sudantribune.com/spip.php?article 59779 (last visited 5 Oct. 2016). There have subsequently been doubts 
authorities arrested and deported hundreds of Eritreans in May 2016. ${ }^{118}$ The European Parliament raised concerns about reports that the RSF had been deployed to patrol Sudan's border with Egypt and Libya in August 2016 and

call[ed] on the EEAS and the Commission to closely monitor EU development assistance in Sudan in order to prevent any direct or indirect support to local militias, and to ensure that RSF forces patrolling Sudan's borders with Egypt and Libya do not purport to fight illegal migration on behalf of the EU. ${ }^{119}$

Sudan proposed the building of two reception centres in Gadaref and Kassala in eastern Sudan, with custody rooms, which EUTF commented upon as "in principle could be funded later". ${ }^{20}$ This measure would enhance the risk of arbitrary arrest and detention, as well as ill-treatment of refugees and migrants, considering that these practices are systemic in Sudan and that those detained in these centres would be particularly vulnerable with no effective access to justice. The prospect of funding such centres has for these reasons attracted widespread criticism. ${ }^{121}$ The building of such centres has now been ruled out. ${ }^{122}$

The third BMM action concerns "assistance to victims of trafficking and vulnerable smuggled migrants to ensure access to appropriate services, including access to justice." 123 This is clearly important and projects such as those proposed by Sudan may have some positive impact: "Improved migration management capacity and services (friendly entry and exit processing and assistance for victims and vulnerable people)." ${ }^{124}$ However, systemic concerns

concerning the veracity of claims made by the RSF, and suggestions that the arrest of migrants was fabricated in order to put pressure on the EU, which distanced itself from allegations that it was funding the RSF. "EU: 'No support to Sudan's RSF"', Radio Dabanga, 6 Sept. 2016, available at: www.dabangasudan.org/en/allnews/article/eu-no-support-to-sudan-s-rsf (last visited 5 Oct. 2016). See further Amnesty International, Human rights impacts, 2-4.

${ }^{118}$ Human Rights Watch, "Sudan: Hundreds Deported to Likely Abuse", New York, 30 May 2016. See further Baldo, Border Control from Hell.

${ }^{119}$ EP resolution, 6 Oct. 2016, 15.

${ }^{120}$ EUTF, Better Migration Management, 13.

121 J. Dahlkamp and M. Popp, "Questionable Deal: EU to Work with African Despot to Keep Refugees Out", Spiegel Online International, 13 May 2016, available at: www.spiegel.de/international/world/eu-to-work-withdespot-in-sudan-to-keep-refugees-out-a-1092328.html (last visited 4 Oct. 2016).

122 Antwort der Bundesregierung, Drucksache 18/8682, para. 16.

123 EUTF, Better Migration Management, 9. GIZ, Description of the Action, 16: "To improve the identification, assistance and protection of victims of trafficking (VoT) and vulnerable migrants, especially women and children, in the $[\mathrm{HoA}] . "$

${ }^{124}$ EUTF, ibid., 13. 
about Sudan's laws and institutions apply equally to a system that lacks legislation, facilities, experts and an institutional culture in the field of victim and witness protection, as well as effective access to justice. Sudanese authorities reported a number of operations and arrests of suspected smugglers and traffickers, as well as the "release of hundreds of victims". ${ }^{125}$ Yet, reports noting the lack of adequate protection accorded to trafficking victims in Sudan suggest that the risk identified in the BMM that "victims of smugglers and traffickers continue being criminalised for irregular immigration, prostitution, petty crimes and not treated as victims" ${ }^{126}$ is genuine and reflective of actual practice. According to the US Trafficking in Persons Report 2016:

Although the government reported law enforcement efforts against trafficking offenders, officials frequently conflated trafficking with other crimes, such as smuggling and kidnapping, and convicted offenders received severely weak sentences that were insufficient to deter the crime. ... The government identified a significant number of victims of abuse, including some trafficking victims, during security operations; however, the government failed to identify victims of sex trafficking or forced labor. Authorities continued to punish trafficking victims for unlawful acts committed as a direct result of being subjected to trafficking, such as immigration violations. The government lacked capacity and resources to provide adequate protective services to all forms of trafficking. ${ }^{127}$

The fourth BMM action consists of the "launch of information campaigns and community conversations, targeting communities of origin and transit of migrants, on risk of irregular migration, including trafficking in human beings and alternatives to irregular migration."128 Its apparent thrust is dissuasion of would-be, "irregular" migrants. Notably, there is no reference to any information on legal migration or the rights of migrants and refugees. The main assumption for the success of this component is that the "target population has access to radio and other

\footnotetext{
${ }^{125}$ Sahan/Igad, Human Trafficking and Smuggling, 34.

${ }^{126}$ EUTF, Better Migration Management, 9.

${ }^{127}$ US Department of State, Trafficking in Persons Report, Jun. 2016, 349 (similarly, Trafficking in Persons Report, 2017, 372). In response, see "Sudan slams U.S. report on human trafficking", Sudan Tribune, 4 Jul. 2016, available at: www.sudantribune.com/spip.php?article59507 (last visited 5 Oct. 2016).

${ }^{128}$ EUTF, Better Migration Management, 8. GIZ, Description of the Action, 23: "To raise awareness of alternative livelihood options including safe migration."
} 
media and is able to read written information sheets." ${ }^{29}$ Sudan has proposed "[a]wareness raising and promotion of legal migration (government institutions, civil society and the media)." 130 This action is based on the premise that the government concerned is a trustworthy and effective communicator, which only needs access to appropriate media to convey relevant messages to a receptive audience. The BMM has now adopted an approach that primarily relies on civil society organisations as partners. ${ }^{131}$ Ultimately, information campaigns and community conversations are unlikely to succeed as long as the root causes of migration, including poverty, underdevelopment and human rights violations, persist, which prompt individuals to take risks by means of using irregular migration routes.

The foregoing scrutiny of the BMM demonstrates the inadequacy of a project management approach, that is a technical approach to a political and economic crisis, as a mode of governance to achieve broader policy objectives. This approach is based on the assumption of cooperation by reliable partners who are capable of satisfactorily implementing projects in the legally complex and highly challenging areas of migration law and criminal justice, which ignores the systemic rule of law failings of national systems. Engagement "with repressive governments on migration (particularly in Eritrea and Sudan)" does not only carry the reputational risk identified by EUTF. ${ }^{132}$ It also raises fundamental concerns about the ability of such governments to implement specific projects in the absence of more far-reaching, mid- to long-term legal, institutional and political reforms. A partnership model driven by migration control imperatives based on Western models of refugee protection further risks transforming traditional modes of receiving refugees, such as replacing group recognition with restrictive individual screening in Sudan. This is complemented by concerns of officials working in the field of migration and refugee law that the politicised top-down approach will result in

\footnotetext{
${ }^{129}$ EUTF, ibid., 9.

${ }^{130}$ Ibid., 13.

${ }^{131}$ GIZ, Description of the Action, 23-26.

${ }^{132}$ EUTF, Better Migration Management, 9, and, more broadly, leaked document, Council of the European Union, Joint Commission-EEAS non-paper on enhancing cooperation on migration, mobility and readmission with Sudan, 7203/16, 17 March 2016, 3: "The EU should carefully consider the high reputational risk associated with its engagement with Sudan if exclusively focused on migration", available at www.statewatch.org/news $/ 2016 / \mathrm{mar} / \mathrm{eu}-$ com-eeas-readmission-sudan-7203-16.pdf (last visited 5 Oct. 2016).
} 
militarisation of the border and a preference for taking measures that are incompatible with a rights-based approach. ${ }^{133}$

The project management model and mitigating measures conceived in political and technical terms are patently inadequate to ensure an adequate level of rights protection in the absence of what must be considered basic human rights safeguards and monitoring procedures. There are no benchmarks and narrow quantitative indicators only. ${ }^{134}$ The monitoring of implementation appears to be guided by a project-based rather than a human rights-based approach. ${ }^{135}$ The ignorance of structural factors impacting implementation and the lack of robust monitoring and review therefore make it highly unlikely that the expected results can be achieved in conformity with respect for applicable rights within the limited parameters of the programme.

\section{COHERENCE OF EU EXTERNAL ACTION AND HUMAN RIGHTS PROTECTION}

Article 21(1) of the TEU stipulates that:

The Union's action on the international scene shall be guided by the principle which have inspired its own creation, development and enlargement, and which it seeks to advance in the wider world: democracy, the rule of law, the universality and indivisibility of human rights and fundamental freedoms, respect for human dignity, the principles of equality and solidarity, and respect for the principles of the United Nations Charter and international law.

The Union shall seek to develop relations and build partnerships with third countries, and international, regional or global organisations which share the principles referred to in the first subparagraph.

\footnotetext{
133 Amaar, "Interview with Mr. Is`mail Omar Tairab."

${ }^{134}$ See indicative logical framework, EUTF, Better Migration Management, 15.

${ }^{135}$ GIZ, Description of the Action, 45-46.
} 
Most HoA States participating in the Khartoum Process have a poor record in respect of human rights protection. As recognised by EUTF, this applies particularly to Eritrea and Sudan. ${ }^{136}$ The UN Commission of Inquiry on Human Rights in Eritrea found that "systematic, widespread and gross human rights violations have been and are being committed in Eritrea under the authority of the Government." 137 As a consequence, "hundreds of thousands of Eritreans are fleeing the country... Eritreans are fleeing severe human rights violations in their country and are in need of protection." ${ }^{\prime 38}$ On the administration of justice, the Commission noted pithily: "It is not law that rules Eritreans, but fear." ${ }^{139}$ Similarly, a large number of UN reports, decisions by the ACHPR and civil society reports, have documented Sudan's responsibility for gross violations of international human rights law and serious violations of international humanitarian law in the course of armed conflicts in Darfur, South Kordofan and Blue Nile. ${ }^{140}$ Several high-ranking officials, including Sudan's President Omar al-Bashir, are subject to International Criminal Court (ICC) arrest warrants for international crimes. ${ }^{141}$ As various bodies have expressed concerns about the lack of respect for the rule of law and human rights in both Eritrea and Sudan, the two States in particular ${ }^{142}$ cannot be credibly characterised as countries that share the principles referred to in the first subparagraph of article 21(1) TEU.

Article 21(2)(a) TEU sets out as the objective of EU cooperation in international relations the safeguarding of the EU's "values, fundamental interests, security, independence and integrity". Migration control has a bearing on several of these objectives. However, article 21(2) (b) also underscores the objective of "consolidate[ing] and support[ing] democracy, the rule of law, human rights and the principles of international law." Article 21(3) exhorts the EU to "respect the principles and pursue the objectives set out in paragraphs 1 and 2 " in its external

\footnotetext{
${ }^{136}$ Ibid., 9.

${ }^{137}$ Report of the commission of inquiry on human rights in Eritrea, UN Doc. A/HRC/29/42, 4 Jun. 2015 , para. 23.

${ }^{138}$ Ibid., para. 26.

${ }^{139}$ Ibid., para. 38.

${ }^{140}$ Report of International Commission of Inquiry, Darfur; Sudanese civilians in South Kordofan and Blue Nile (represented by REDRESS, SDFG, HRW and the Enough Project) v. Sudan, Communication 420/12 (joined with 402/11), pending before ACHPR; S. Totten (ed.), Conflict in the Nuba mountains: from genocide by attrition to the contemporary crisis, London, Routledge, 2014.

${ }^{141}$ See for more detailed information the ICC website, available at: www.icc-cpi.int/darfur (last visited 5 Oct. 2016) and Twenty-third report of the Prosecutor.

${ }^{142}$ It is also questionable whether other participating States from the HoA meet the criteria set out in art. 21(1) TEU. See on Ethiopia, Reitano, The Khartoum Process, 9.
} 
action, and to "ensure consistency between the different areas of its external action and between these and its other policies."

There is a clear tension between the Khartoum Process and the EU's human rights policy, ${ }^{143}$ which threatens coherence ${ }^{144}$ and consistency of action between the areas of migration and human rights protection. Co-operating with States such as Eritrea and Sudan on issues of migration entails the risk that the EU and its member States are less willing to insist on human rights protection and on holding co-operating States and responsible individuals to account. For the Khartoum Process to be successful, participating States must be treated and perceived as legitimate partners. ${ }^{145}$ These States are aware of the EU's interest in making the Khartoum Process work, and may use this to gain concessions. Sudan has already done so by calling for support for the lifting of sanctions, debt relief and its removal from the list of States sponsoring terrorism in return for its cooperation in migration control measures. ${ }^{146}$ It may also threaten noncooperation in response to any criticism over its human rights record. The approach taken in the Khartoum Process is part of broader, at times contradictory international engagement vis-à-vis Sudan, over the last decade, and recent rapprochement that increasingly treats Sudan as a reliable actor if not partner in the region, and downplays human rights concerns. ${ }^{147}$ It is difficult to see how this approach can be reconciled with the Council of the EU's "Strategic Framework for the Horn of Africa" objective of supporting "the people of the region in achieving peace, stability, security, prosperity and accountable government."148 The recently adopted EU HoA Regional Action Plan identifies both migration and "[v]iolations of human rights, absence of the rule of

\footnotetext{
${ }^{143}$ See in particular Council conclusions on Human Rights and Democracy, the EU Strategic Framework on Human Rights and Democracy, EU Action Plan on Human Rights and Democracy, Council of the European Union, 11855/12, 25 Jun. 2012. See on the role of the Cotonou Agreement, from which Sudan withdrew in 2009, Baldo, Border Control from Hell, 3.

${ }^{144}$ D. Wunderlich, "Towards Coherence of EU External Migration Policy? Implementing a Complex Policy", International Migration, 51(6), 2013, 26-40, 28: "Coherence can be understood in a positive sense as policy components contributing to an overarching objective or, in a negative sense, as a minimum of policy contradictions."

${ }^{145}$ Stern, Khartoum Process, 15, neatly captures the political tensions that may undermine the effectiveness of the Khartoum Process: "Either the Process gains more public attention than intended and faces strong political opposition in Europe, or the African States are dissatisfied with the low political attention they get from their European partners, which will seriously harm the effectiveness of the process."

${ }^{146}$ Joint Commission-EEAS non-paper, 3.

${ }^{147}$ See further Pax, Sudan Alert: The EU's policy options for Sudan, Utrecht, 2016.

${ }^{148}$ Council of the European Union, "Council conclusions on the Horn of Africa", $3124^{\text {th }}$ Foreign Affairs Council meeting, Brussels, 14 Nov. 2011, Annex, 3 (emphasis added).
} 
law and authoritarian governance" ${ }^{, 49}$ as challenges but is silent on how to address the inevitable tensions between policy approaches in this regard.

The Khartoum Process risks failing to meet the EU's obligation ("shall") to "ensure consistency and coherence between its instruments and policies in all areas of its external and internal action in relation to the most serious international crimes as referred to in the Rome Statute." ${ }^{150}$ In the implementation of the Khartoum Process, the EU does not directly interact with individuals subject to an arrest warrant by the ICC. However, it engages with representatives of, and, at least indirectly, relies on forces, such as the NISS and RSF who are alleged to have been responsible for crimes falling within the ICC's remit. ${ }^{151}$

The approach taken in the Khartoum Process also raises questions about the coherence of the EU's, particularly the European Commission's, external action in the field of migration. This concerns the need to address all areas of the EU's policy of better migration management, including EU policy on channels of legal migration. ${ }^{152}$ It comprises rights protection, as " $[\mathrm{t}]$ he impact on fundamental rights of initiatives taken in the context of the GAMM must be thoroughly assessed." 153 Further, "[t]he GAMM should strengthen respect for fundamental rights and the human rights of migrants in source, transit and destination countries alike."154 There is no indication how this objective can be achieved without far-reaching reforms in countries such as Eritrea and Sudan whose systematic and systemic human rights violations result in forced displacement and whose authorities have repeatedly violated the rights of citizens and foreign nationals (in the migration context) alike. Instead, the approach taken validates, rather than heeds, François Crépeau's critique of migration management programmes that

[i]t appears much more 'efficient' to do capacity building in transit States so that their authorities will carry out the arrest, detention, and deportation of irregular migrants, and refugee determination procedures if need be. Most of those countries do not have the same

\footnotetext{
149 "Council Conclusions on the EU Horn of Africa Regional Action Plan 2015-2020", COAFR310 ACP 153 CFSP/PESC 686 DEVGEN 205, 13363/15 (2015), 12, 13.

150 Art. 8 "Council Decision 2011/168/CFSP of 21 Mar. 2011 on the International Criminal Court and repealing Common Position 2003/444/CFSP".

${ }^{151}$ See Twenty-third Report of the Prosecutor, para. 15.

152 This has been acknowledged by the European Commission. See European Agenda on Migration, 6: “... a robust fight against irregular migration, traffickers and smugglers, and securing Europe's external borders must be paired with a strong common asylum policy as well as a new European policy on legal migration."

153 Global Agenda on Migration and Mobility, 6.

${ }^{154}$ Ibid., 7.
} 
democratic culture, the same human rights protection infrastructure, the same active and vocal civil society organisations caring for migrants, the same investigative journalism, or the same independent and competent judiciary. From a Global North perspective, these deficiencies are actually considered an asset in 'migration management' because they do not hamper the swift deportation of migrants. ${ }^{155}$

\section{PARAMETERS OF AN ALTERNATIVE APPROACH}

The Khartoum Process in its present form is untenable from a rights perspective. The Process has lacked transparency, and participation and awareness of key actors. It overly focuses on repressive measures to the detriment of broader prevention and responsibility sharing strategies in the area of migration. Its project management approach to fighting human trafficking and smuggling is overly technical, failing to take due account of how EU external migration control policies, the responsibility of partner States for forced migration, and structural rule of law shortcomings adversely impact the successful implementation of planned actions. This is compounded by the lack of clear human rights benchmarks, monitoring and oversight of project implementation. As a result, the Khartoum Process, solemn declarations to the contrary notwithstanding, lacks sufficient guarantees to uphold the rights of refugees and the human rights of migrants. Its effectiveness to prevent trafficking and smuggling and help victims rests on questionable assumptions, and there are already indications that it may have contributed to rights violations. On a broader policy level, the EU and its member States have taken insufficient account of how the Khartoum Process relates to, and negatively impacts, other EU policies, particularly in the field of human rights protection. An end to any cooperation with States in the region would leave the pressing issue of trafficking of vulnerable persons unresolved, and would have considerable political costs. Against this background, the section will sketch out the parameters of a changed approach that is rights compliant, and ensures the greatest possible coherence between various EU policies in the field of external relations. To begin with, the reference to context and root causes in various EU documents on the HoA is overly general, and

\footnotetext{
${ }^{155}$ Crépeau, "Rejecting Criminalisation”, 118.
} 
devoid of any sense of agency. ${ }^{156}$ It obscures the fact that States' policies in the region have contributed to, if not caused the production of refugee flows, and how overly restrictive EU entry policies, in particular the absence of legal migration routes, have played a part in fuelling smuggling and human trafficking. The Khartoum Process therefore addresses symptoms but fails to acknowledge, and tackle key underlying causes. This assessment calls for a more holistic engagement that links an improvement in the human rights and governance situation in the States concerned and changes to the EU external migration policy, by opening channels of legal migration and easing access more generally. ${ }^{157}$ The Commission of Inquiry on human rights in Eritrea has made the link between human rights violations and forced migration explicit, calling on the international community "[i]n engaging with the Eritrean authorities on solutions to stem the flow of asylum seekers from Eritrea, place human rights considerations at the forefront of any package of proposed abatement measures"158 and “[k]eep Eritrea under close scrutiny until tangible progress in the situation of human rights is evident, and ensure the centrality of human rights in all engagement with the country."159

Initiatives such as the Khartoum Process should therefore be based on a broader approach that treats migration as one element of a wider political dialogue that addresses the human rights concerns that lie at the root of most migration in, and from the region. ${ }^{160}$ The current, instrumental and state-centric approach is overly reliant on law enforcement institutions with limited capacity and poor governance and human rights records. Legislative and institutional reforms in this regard need to move beyond the narrow confines of migration related measures in order to guarantee a sound administration of justice in implementing the process. ${ }^{161}$ While a repressive approach to human trafficking and smuggling is mandated by international law, there

\footnotetext{
${ }^{156}$ See e.g. EU, "Council conclusions on the Horn of Africa", 4: "Unaccountable governance and/or corruption mixed with societal tensions or grievance have been violently manifested in some parts of the Horn..." and, ibid., 5: "As elsewhere in Africa, [chronic instability] has reflected weak or ineffective state institutions, and the absence or weakness of the rule of law, making it hard to combat organised crime, terrorism and armed groups." Similarly, in the La Valletta Declaration, 2, participants "commit to address the root causes of irregular migration and forced displacement resulting from state fragility and insecurity, as well as from demographic, economic and environmental trends." (emphasis in original).

${ }^{157}$ UNHCR observations regarding the Rome Conference.

${ }^{158}$ Report, UN Commission of Inquiry, Eritrea, para. 96(g).

${ }^{159}$ Ibid., para. 96(h).

${ }^{160}$ Pax, Sudan Alert, 21.

${ }^{161}$ See e.g. L. Oette and M. A. Babiker, The Rule of Law and Human Rights in Sudan: challenges and prospects for reform, Sudan Democracy First Group, Institutional Reform Series (2), 2014.
} 
is an equal duty, and considerable scope for preventive approaches. ${ }^{162}$ This includes a focus on the drivers of forced migration and vulnerability in the region, which calls for an evidence-led approach that is based on the participation, and needs of affected communities, civil society representatives and other actors working in the field. There is also scope to listen more carefully to a range of African actors, and how they conceive of the problems they face and ways to tackle them. This includes opening channels for legal migration within the region and in Europe, supporting refugees in host countries, and engaging in broader development initiatives, without, however, making development assistance conditional on migration control, or treating development as a containment device. ${ }^{163}$ EUTF is already funding some projects to this end, ${ }^{164}$ notably including a "special support measure in favour of the people of the Republic of Sudan" that focuses on support to basic services, livelihoods and food security and to civil society, local governance and peace-building. ${ }^{165}$ While important, these measures are likely to remain piecemeal and insufficient to address the broader challenges outlined above unless migration is viewed as a genuinely joint responsibility and linked to broader human rights concerns.

Respect for refugee rights and human rights is referenced in several EU documents. ${ }^{166}$ This is important but needs to be complemented by adequate mechanisms in order to ensure that such respect becomes integral to any actions under the Khartoum Process. Transparency at all levels, i.e. EU, AU, national States, and all stages of the process is vital to ensure scrutiny and address any concerns at the earliest possible stage. This transparency can be fostered by broader participation in policy-making of a cross-section of actors in the field, including UNHCR and the UN Special Rapporteur on the Human Rights of Migrants, and consultation of civil society representatives, particularly from the HoA itself. The mode of implementation needs to move

\footnotetext{
${ }^{162}$ Art. 9 Palermo Protocol.

${ }^{163}$ See M. Clemens, "Does Development Reduce Migration?" Centre for Global Development, Working Paper 359, Mar. 2014, who concludes that: “... this suggests that today's typical poor countries are unlikely to exhibit lower emigration rates as they develop - 1) until they reach income levels in the upper range of middle-income countries, and 2) unless they follow patterns of demographic and structural transition markedly different from developing countries in the past. If anything they are likely to exhibit somewhat higher rates of emigration as they develop" and “... there is enough evidence now ... for policymakers to move beyond 'development instead of migration policies",

${ }^{164}$ See EUTF: "Status of Contracts", available at: https://ec.europa.eu/europeaid/regions/africa/eu-emergency-trustfund-africa_en (last visited 5 Oct. 2016).

${ }^{165}$ See N. Mimica, "EU and Sudan to strengthen dialogue and cooperation", Sudan Tribune, 6 Apr. 2016, available at: www.sudantribune.com/spip.php?article 58546 (last visited 5 Oct. 2016).

${ }^{166}$ GAMM, Rome Declaration, La Valletta Declaration.
} 
from a project management approach that largely relies on project based evaluation to a human rights model that sets out clear benchmarks, monitoring procedures by independent entities or observers, and sanctions in case of violations of refugee rights or human rights of migrants. Monitoring is to encompass all aspects of project implementation, including adequate use of any equipment and funds received or used by partner States.

\section{CONCLUSION}

The Khartoum Process is part of multiple EU policy responses to the complex challenges of large-scale mixed migration and organised transnational crime. The EU has a legitimate interest to take action that seeks to address these challenges. The Khartoum Process, however, represents a model that is flawed on many counts. It forms part of informal, ad-hoc policy responses to the "refugee crisis", ${ }^{167}$ primarily by further externalising migration control, which undermine efforts to develop a coherent framework for global migration governance. ${ }^{168}$ The review of the underlying assumptions and logic of implementation confirms the validity of studies critical of such informal modes of governance and their inadequate design and focus from the perspective of a human rights-based framework.

The HoA faces a crisis. Mixed migration, including human smuggling and trafficking, is amongst its many symptoms. The root causes are deep-seated and require fundamental reforms that help establish peaceful and stable States. Any external action in the field of migration in a region such as the HoA constitutes a serious political, legal and practical challenge for the EU and concerned States. The findings of our analysis suggest that the EU and other policy makers have paid insufficient attention to these challenges, ignoring the considerable body of literature, and the UN Special Rapporteur on the human rights of migrants, who have repeatedly raised concerns about the nature of regional initiatives and partnerships and their adverse impact on rights protection. Partnering with States responsible for repression and conflict is particularly, and inherently, problematic. Firmly establishing human rights protection as an overriding objective that reaches beyond the scope of any issue-specific engagement is an imperative foundation for any engagement in such a context. This finding is not only relevant in the specific

\footnotetext{
167 See on this point, C. Dauvergne, "Refugee law as perpetual crisis", in S.S. Juss and C. Harvey (eds.), Contemporary Issues in Refugee Law, Cheltenham, Edward Elgar, 2013, 13-30.

${ }^{168}$ Report of the Special Rapporteur, Aug. 2013, paras. 69-76.
} 
context of the HoA but should inform policy making at the international level, particularly in the debates on the Global Compact for Migration, and at the regional level in the pursuit of EU external action on migration. Considering the future of the Khartoum Process, cooperation must not entail an expectation that the EU and its member States will compromise on human rights protection. An important means to ensure this is to effectively engage civil society and communities, particularly in the affected regions, and relevant national, regional and subregional institutions in the policy formulation and implementation of projects under the Khartoum Process and related activities on migration in the HoA. The failure to engage local actors beyond State representatives risks conveying the message, all too familiar in the region, that political projects serve the interests of elites who ignore the legitimate expectations, and suffering of those they rule (and are supposed to represent). It also carries echoes of colonial powers using local chiefs to tame the restless "natives". ${ }^{169}$ Fundamental changes to the Khartoum Process, and the EU's policy on migration more broadly, are therefore overdue if the EU wants to take seriously its self-proclaimed image as guardian of democracy, peace, human rights and the rule of law, both at home and abroad.

${ }^{169}$ See e.g. C. Vaughan, Darfur: Colonial Violence, Sultanic Legacies \& Local Politics, 1916-1956, Woodbridge, James Currey, 2015. 